\title{
Upregulation of RSPO2-GPR48/LGR4 signaling in papillary thyroid carcinoma contributes to tumor progression
}

\author{
Yea Eun Kang ${ }^{1, *}$, Jin-Man Kim ${ }^{2,3, *}$, Koon Soon Kim ${ }^{1,2, *}$, Joon Young Chang ${ }^{2}$, Mingyu \\ Jung ${ }^{2}$, Junguee Lee ${ }^{4}$, Shinae $\mathrm{Yi}^{2}$, Hyeon Woo Kim², Jung Tae Kim², Kyungmin Lee ${ }^{2}$, \\ Min Jeong Choi ${ }^{2}$, Seul Ki Kang ${ }^{2}$, Seong Eun Lee ${ }^{2}$, Hyon-Seung Yi', Bon Seok Koo ${ }^{2,5}$ \\ and Minho Shong ${ }^{1,2}$ \\ ${ }^{1}$ Department of Endocrinology and Metabolism, College of Medicine, Chungnam National University, Daejeon 35015, South \\ Korea \\ ${ }^{2}$ Department of Medical Science, College of Medicine, Chungnam National University, Daejeon 35015, Republic of Korea \\ ${ }^{3}$ Department of Pathology, College of Medicine, Chungnam National University, Daejeon 35015, Republic of Korea \\ ${ }^{4}$ Department of Pathology, Daejeon St. Mary's Hospital, College of Medicine, The Catholic University of Korea, Daejeon \\ 34943, Republic of Korea \\ ${ }^{5}$ Department of Otolaryngology-Head and Neck Surgery, College of Medicine, Chungnam National University, Daejeon 35015, \\ Republic of Korea \\ *These authors have contributed equally to this work \\ Correspondence to: Minho Shong, email: minhos@cnu.ac.kr \\ Keywords: RSPO2; GPR48/LGR4; papillary thyroid carcinoma; BRAF ${ }^{\mathrm{V} 600 \mathrm{E}}$ mutation; $\beta$-catenin pathway \\ Received: June 19,2017 Accepted: October 04, $2017 \quad$ Published: November 25, 2017 \\ Copyright: Kang et al. This is an open-access article distributed under the terms of the Creative Commons Attribution License 3.0 \\ (CC BY 3.0), which permits unrestricted use, distribution, and reproduction in any medium, provided the original author and source \\ are credited.
}

\section{ABSTRACT}

The signaling pathway involving the $\mathbf{R}$-spondins and its cognate receptor, GPR48/LGR4, is crucial in development and carcinogenesis. However, the functional implications of the R-spondin-GPR48/LGR4 pathway in thyroid remain to be identified. The aim of this study was to investigate the role of R-spondin-GPR48/ LGR4 signaling in papillary thyroid carcinomas. We retrospectively reviewed a total of 214 patients who underwent total thyroidectomy and cervical lymph node dissection for papillary thyroid carcinoma. The role of GPR48/LGR4 in proliferation and migration was examined in thyroid cancer cell lines. R-spondin 2, and GPR48/ LGR4 were expressed at significantly higher levels in thyroid cancer than in normal controls. Elevated GPR48/LGR4 expression was significantly associated with tumor size $(P=0.049)$, lymph node metastasis $(P=0.004)$, recurrence $(P=0.037)$, and the BRAFV600E mutation ( $P=0.003)$. Moreover, high GPR48/LGR4 expression was an independent risk factor for lymph node metastasis $(P=0.027)$ and the BRAFV600E mutation $(P=0.009)$. in vitro assays demonstrated that elevated expression of GPR48/LGR4 promoted proliferation and migration of thyroid cancer cells, whereas downregulation of GPR48/LGR4 decreased proliferation and migration by inhibition of the $\beta$-catenin pathway. Moreover, treatment of thyroid cancer cells with exogenous R-spondin 2 induced activation of the $\beta$-catenin pathway through GPR48/LGR4. The R-spondin 2-GPR48/LGR4 signaling axis also induced the phosphorylation of ERK, as well as phosphorylation of LRP6 and serine 9 of GSK3 $\beta$. Our findings demonstrate that upregulation of the R-spondin 2-GPR48/LGR4 pathway contributes to tumor aggressiveness in papillary thyroid carcinoma by promoting ERK phosphorylation, suggesting that this pathway represents a novel therapeutic target for treatment of differentiated thyroid cancer. 


\section{INTRODUCTION}

G-protein coupled receptors (GPCRs), including thyrotropin receptor, are important in both normal thyrocytes and differentiated thyroid cancer cells [1]. Recently, a group of GPCRs named leucine-richrepeat-containing G-protein-coupled receptors (LGRs) were studied as regulators of both organogenesis and carcinogenesis [2-4]. GPR48/LGR4 is related to LGR5 and LGR6, with approximately 50\% amino acid identity among the three proteins, and is widely expressed in multiple tissues from the early stages of embryogenesis to adulthood [5, 6]. In a previous study, endogenous GPR48/LGR4 expression was monitored by gene reporter assays in transgenic mice: the protein was localized to the Rathke's pouch in E14 mouse embryos, and expressed in some cells at the border of follicles in the adult mouse thyroid [7]. The GPR48/LGR4 mRNA is also present in normal human thyroid tissue, as revealed by Northern blot analysis, but relatively few studies have investigated the role of GPR48/LGR4 in human thyroid diseases $[5,6]$.

Recent studies show that the R-spondin (RSPO) family, a group of four newly identified secreted proteins, promotes $\mathrm{Wnt} / \beta$-catenin signaling. The $\mathrm{Wnt} / \beta$-catenin is essential in embryonic development as well as in self-renewal and maintenance of adult stem cells. Their biological effects are mediated by high-affinity binding to LGR receptors and sequential induction of LRP6 phosphorylation [8-11]. Lack of RSPO2 signaling in the embryonic stage results in thyroid malformation $[12,13]$. These findings showed that the RSPO signaling axis is indispensable for normal development of the thyroid gland in animal models, but the expression status and roles of RSPO-GPR48/LGR4 signaling components in human thyroid gland remain to be elucidated.

However, several lines of evidence indicate that GPR48/LGR4 participates in carcinogenesis. Elevated GPR48/LGR4 expression in cancer tissue is significantly correlated with regional metastasis, and upregulation of GPR48/LGR4 promotes cell proliferation in multiple cancers by stimulating $\mathrm{Wnt} / \beta$-catenin signaling $[14,15]$. Upregulation of GPR48/LGR4 expression, associated with downregulation of $\mathrm{P} 27^{\mathrm{kip} 1}$, promotes invasiveness and metastasis in colorectal carcinoma cells [16]. In addition, GPR48/LGR4 contributes to tumor metastasis by stimulating $\beta$-catenin/TCF signaling, and is associated with poor prognosis in colorectal cancer [17]. GPR48/ LGR4 is also overexpressed in prostate cancer, concomitant with activation of the PI3K/AKT signaling pathway [18]. Thus, GPR48/LGR4 signaling may promote tumorigenesis by potentiating $\mathrm{Wnt} / \beta$-catenin activity, which is elevated in thyroid cancer $[19,20]$.

Based on this premise, we investigated the RSPO-GPR48/LGR4 signaling axis in normal thyroid gland and papillary thyroid carcinomas (PTCs). We observed that RSPO2 and its receptor, GPR48/
LGR4, were expressed in normal thyroid gland and at higher levels in in PTCs, particularly in patients with regional tumor progression, including lymph node (LN) metastasis. In addition, elevated expression of GPR48/ LGR4 promoted proliferation and migration of thyroid cancer cells, whereas downregulation of GPR48/LGR4 decreased proliferation and migration by inhibiting the $\beta$-catenin pathway. Collectively, our results indicate that upregulation of the RSPO2-GPR48/LGR4 signaling axis promotes tumor aggressiveness in PTCs.

\section{RESULTS}

\section{Expression of GPR48/LGR4 in human normal thyroid gland and thyroid carcinomas}

First, we sought to measure the expression of GPR48/LGR4 in normal human thyroid gland. For this purpose, we obtained normal thyroid tissue from contralateral lobes of thyroid glands removed during surgery for differentiated thyroid cancer. GPR48/LGR4 was weakly positive in the nucleus and cytoplasm of normal follicular epithelium (Figure 1A). The solid cell nests (SCNs) of the human thyroid are ultimobranchial body remnants that may be the origin of pluripotent cells contributing to folliculogenesis, as well as formation of some thyroid tumors [21, 22]. LGRs, which have recently attracted attention as markers of adult stem cells, are important for maintenance of stem cell functions. To determine whether GPR48/LGR4 represents a marker of a specific population of SCNs, we observed GPR48/LGR4 immunoreactivity in SCNs. As shown in Figure 1B, cells forming SCNs did not exhibit significant immunoreactivity against either Nkx2.1 or GPR48/LGR4, although p63, an epithelial stem cell marker, exhibited consistently higher expression in SCNs. Thus, GPR48/LGR4 is only expressed in normal thyroid follicular epithelium, but is rarely expressed in embryonic remnants.

In PTC, the expression pattern of GPR48/LGR4 differed from that in normal thyroid gland. Most tumor cells in PTCs were GPR48/LGR4-positive, and the staining was more intense than in normal follicular cells positive for this marker (Figure 1C). Staining of GPR48/ LGR4 was distributed in the membrane and cytoplasm, but not the nucleus. Additionally, we compared the intensity and distribution of GPR48/LGR4 staining in normal thyroid and tumor tissues of patients with PTC (Figure 1D). Interestingly, invasive fronts of tumor tissues exhibited high levels of GRP48/LGR4 staining, and GPR48/LGR4 was more intensely and extensively expressed in tumor lesions than in normal tissue (Figure 1D). To investigate the expression of GPR $48 / L G R 4$ mRNA in human PTC, we analyzed paired clinical specimens of tumor and non-tumor tissues from six patients with PTC by RT-PCR. The results revealed that expression of GPR48/LGR4 mRNA was $\sim 1.75$-fold higher 
in PTC tissues than in normal tissues (Figure 1E; $P<0.05$ ). Moreover, expression of the mRNA encoding RSPO2, a secreted Wnt agonist that is one of the endogenous ligands of GPR48/LGR4, was 2.6-fold higher than in normal tissues (Figure 1F; $P<0.05$ ). Expression of the mRNA encoding RSPO3, another secreted Wnt agonist and endogenous ligand of GPR48/LGR4, did not differ significantly between tumor and normal tissues (data was not shown). Expression of $\mathrm{RSPO} 1$ and $\mathrm{RSPO} 4$ mRNA was not detectable in thyroid tissues. These data suggest that GPR48/LGR4 and its ligand RSPO2 are overexpressed in human PTC. We evaluated protein expression in lysates from normal and PTC tissue specimens to confirm the differential expression of GPR48/LGR4 between tumor and normal tissues. As shown in Figure 1G, GPR48/ LGR4 was detectable in both tumors and normal tissue, but expression was more intense in tumors.

\section{Correlation between immunoreactivity of GPR48/LGR4 and clinicopathologic features of patients with differentiated thyroid carcinoma}

Next, to evaluate the relationship between GPR48/ LGR4 immunoreactivity and clinicopathologic features of PTC, we first characterized clinicopathologic features of 214 patients treated for PTC at Chungnam National University Hospital from 2003 to 2010. Clinicopathologic characteristics of enrolled patients are provided in Table 1 . The mean age of the study subjects was 48.4 years (range, 22-84), the majority of the patients were female $(81.8 \%)$, and the average size of the primary tumor was $1.1 \pm 0.8 \mathrm{~mm}$. The proportion of patients with multicentricity was $41.6 \%$ (89/214); capsular invasion, 75.7\% (162/214); extra-thyroid extension, $70.1 \%$ (150/214); and lymphovascular invasion, 79.9\% (171/214). Of the 214 PTC patients, 63.1\% (135/214) had LN metastases and 19.2\% (41/214) had lateral neck LN metastases. Recurrence was observed in 7.5\% (16/214) of patients, and the mean follow-up period was $46.1 \pm 22.9$ months. GPR48/LGR4 immunoreactivity was detected in $97.7 \%(209 / 214)$ of cases. To quantify immunoreactivity of GPR48/LGR4 and BRAF ${ }^{\mathrm{V} 600 \mathrm{E}}$ in PTC, we adopted a scoring system that combined the intensity and the distribution of positive staining: 0 , no staining; +1 , weak staining in focal tumor areas; +2 , moderate staining in most tumors; and +3 , strong staining in most tumors. Representative images of GPR48/LGR4 staining and $\mathrm{BRAF}^{\mathrm{V} 600 \mathrm{E}}$ staining are shown in Supplementary Figure 1A
A
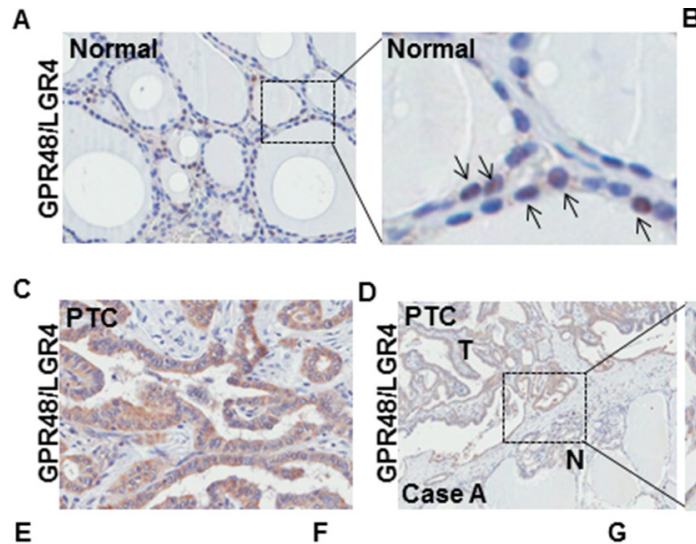

E

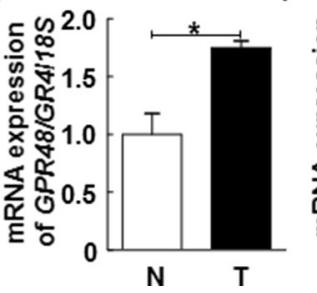

G
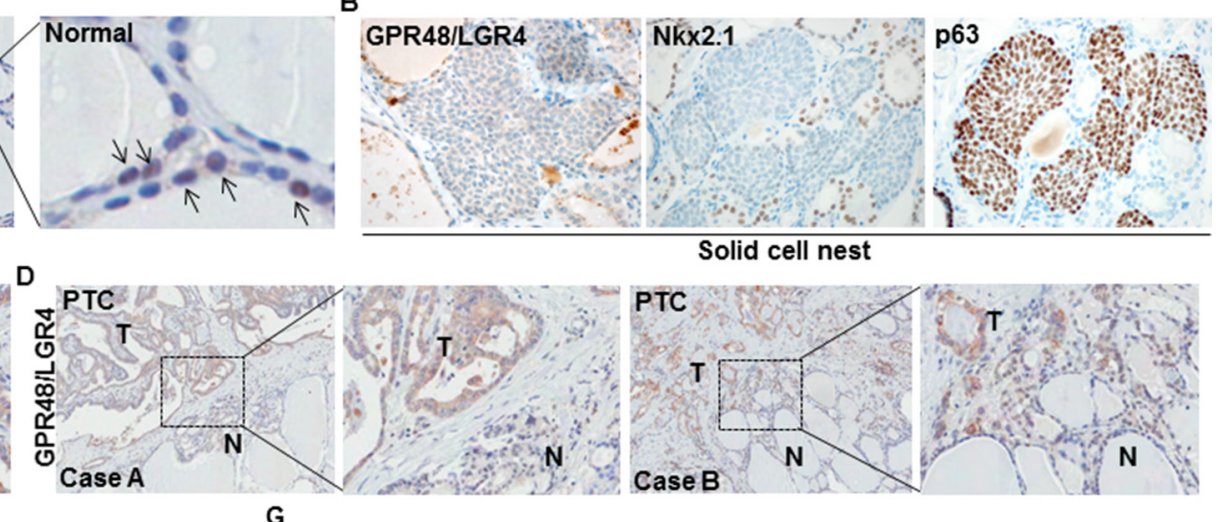

Solid cell nest



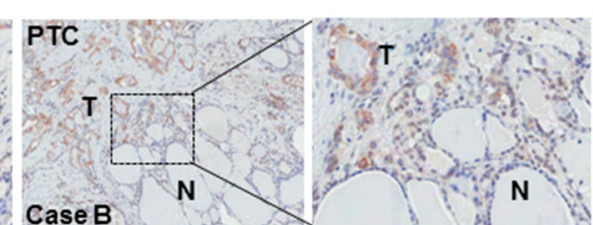

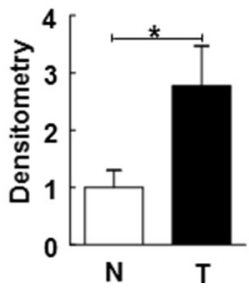

Figure 1: Representative expression of GPR48/LGR4 in human normal thyroid and thyroid carcinomas. (A) Representative images of normal human thyroid gland immunostained for GPR48/LGR4 (brown) and counterstained with hematoxylin, along with $4 \times$ enlarged images. Arrows indicate GPR48/LGR4-positive follicular cells. Magnification: 200× and 800×. (B) Representative images of SCNs in human thyroid gland immunostained for GPR48/LGR4, Nkx2.1, and p63. Magnification: 200×. (C) Representative photos of human PTCs immunostained for GPR48/LGR4 (brown) and counterstained with hematoxylin. Magnification: 200×. (D) Representative expression of GPR48/LGR4 in tumors and corresponding normal thyroid tissue of PTCs, along with $4 \times$ enlarged images. Magnification: $100 \times$. N, normal tissue; T, tumor tissue. (E) GPR48/LGR4 mRNA levels in total cell lysates acquired from paired clinical specimens of normal $(\mathrm{N})$ and tumor (T) tissues, examined by RT-PCR of specimens from six patients with PTC. (F) RSPO2 mRNA levels in total cell lysates acquired from paired clinical specimens of normal $(\mathrm{N})$ and tumor $(\mathrm{T})$ tissues, examined by RT-PCR of specimens from six patients with PTC. (G) Representative images of immunoblot analysis for detection of GPR48/LGR4 in paired clinical specimens of normal $(\mathrm{N})$ and tumor $(\mathrm{T})$ tissues. ${ }^{*}, P<0.05$. 
Table 1: Clinicopathologic parameters of patients

\begin{tabular}{|c|c|c|}
\hline Variables & & Mean \pm SD or number of patients $(\%)$ \\
\hline Age, years & & $48.4 \pm 12.9$ \\
\hline \multirow[t]{2}{*}{ Gender } & Male & $39(18.2)$ \\
\hline & Female & $175(81.8)$ \\
\hline \multirow[t]{2}{*}{ Tumor size } & $\leq 1 \mathrm{~cm}$ & $85(39.7)$ \\
\hline & $>1 \mathrm{~cm}$ & $129(60.3)$ \\
\hline \multirow[t]{2}{*}{ Multicentricity } & No & $125(58.4)$ \\
\hline & Yes & $89(41.6)$ \\
\hline \multirow[t]{2}{*}{ Microscopic capsular invasion } & No & $52(24.3)$ \\
\hline & Yes & $162(75.7)$ \\
\hline \multirow[t]{2}{*}{ Extrathryoid extension } & No & $64(29.9)$ \\
\hline & Yes & $150(70.1)$ \\
\hline \multirow[t]{2}{*}{ Lymphovascular invasion } & No & $43(20.1)$ \\
\hline & Yes & $171(79.9)$ \\
\hline \multirow[t]{2}{*}{ Lymph node metastasis } & No & $79(36.9)$ \\
\hline & Yes & $135(63.1)$ \\
\hline \multirow[t]{2}{*}{ Central lymph node metastasis } & No & $79(36.9)$ \\
\hline & Yes & $135(63.1)$ \\
\hline \multirow[t]{2}{*}{ Lateral lymph node metastasis } & No & $173(80.8)$ \\
\hline & Yes & $41(19.2)$ \\
\hline \multirow[t]{2}{*}{ Locoregional recurrence } & No & $198(92.5)$ \\
\hline & Yes & $16(7.5)$ \\
\hline \multirow[t]{2}{*}{$\mathrm{BRAF}^{\mathrm{V} 600 \mathrm{E}}$ mutation } & No & $34(15.9)$ \\
\hline & Yes & $180(84.1)$ \\
\hline Follow-up period (months) & & $46.1 \pm 22.9$ \\
\hline
\end{tabular}

and 1B. The distribution of the GPR48/LGR4 staining was as follows: no staining in 5 cases $(2.4 \%)$; weak staining $(+1)$ in $15(20 \%)$; moderate staining $(+2)$ in $42(19.6 \%)$; and strong staining $(+3)$ in $152(71.0 \%)$. The distribution of $\mathrm{BRAF}^{\mathrm{V} 600 \mathrm{E}}$ staining was as follows: no staining in 34 cases (15.9\%); and positive staining [i.e., presence of $\mathrm{BRAF}^{\mathrm{V} 600 \mathrm{E}}$ including weak staining $(+1)$, moderated staining $(+2)$, and strong staining $(+3)]$ in $180(84.1 \%)$. Evaluation of the 16 patients with recurrence revealed recurrent disease, as determined by ultrasonography in 16 $(100 \%)$, by PET-CT in $13(81.3 \%)$, and by neck CT in 4 (25\%). All 16 patients exhibited locoregional recurrence (15 local and 1 locoregional recurrence), confirmed by US-guided FNAB of neck LN. All 16 patients underwent salvage surgery and exhibited no evidence of recurrence at the last follow-up.

Next, we analyzed the relationship between the clinicopathologic parameters and expression of GPR48/
LGR4 in PTCs. For this, the patients were divided into two groups according to GPR48/LGR4 immunoreactivity. In univariate analysis, high expression of GPR48/LGR4 was significantly associated with several clinicopathologic parameters including tumor size $(P=0.050)$, LN metastasis $(P=0.004)$, locoregional recurrence $(P=0.037)$, and presence of $\mathrm{BRAF}^{\mathrm{V} 600 \mathrm{E}}(P=0.003)$ (Table 2$)$. To determine the role of GPR48/LGR4 as an independent determinant of aggressive phenotypes in PTC, multivariate analysis using stepwise logistic regression was conducted on parameters revealed to be significant by the univariate analysis. In the multivariate analysis, high expression of GPR48/LGR4 was an independent risk factor of LN metastasis $(P=0.027, \mathrm{OR}, 3.156)$ and the presence of $\operatorname{BRAF}^{\mathrm{V} 600 \mathrm{E}}(P=0.009, \mathrm{OR}, 4.557)$ (Table 3$)$. Thus, GPR48/ LGR4 positivity was highly associated with markers of tumor aggressiveness. 
Table 2: Relationship between intensity of GPR48/LGR4 staining and clinicopathologic factors in 214 patients

\begin{tabular}{|c|c|c|c|c|c|}
\hline \multirow{2}{*}{ Variables } & & \multirow{2}{*}{ No. of patients } & \multicolumn{3}{|c|}{ LGR4 } \\
\hline & & & Low & High & $P$ value \\
\hline Age, years & $\begin{array}{l}<45 \\
\geq 45\end{array}$ & $\begin{array}{c}81 \\
133\end{array}$ & $\begin{array}{l}25 \\
37\end{array}$ & $\begin{array}{l}56 \\
96\end{array}$ & 0.634 \\
\hline Gender & $\begin{array}{c}\text { Male } \\
\text { Female }\end{array}$ & $\begin{array}{c}39 \\
175\end{array}$ & $\begin{array}{l}10 \\
52\end{array}$ & $\begin{array}{c}29 \\
123\end{array}$ & 0.612 \\
\hline Tumor size & $\begin{array}{l}\leq 1 \mathrm{~cm} \\
>1 \mathrm{~cm}\end{array}$ & $\begin{array}{c}85 \\
129\end{array}$ & $\begin{array}{l}31 \\
31\end{array}$ & $\begin{array}{l}54 \\
98\end{array}$ & $0.050^{*}$ \\
\hline Multicentricity & $\begin{array}{l}\text { No } \\
\text { Yes }\end{array}$ & $\begin{array}{c}125 \\
89\end{array}$ & $\begin{array}{l}35 \\
27\end{array}$ & $\begin{array}{l}90 \\
62\end{array}$ & 0.710 \\
\hline Microscopic capsular invasion & $\begin{array}{l}\text { No } \\
\text { Yes }\end{array}$ & $\begin{array}{c}52 \\
162\end{array}$ & $\begin{array}{l}15 \\
47\end{array}$ & $\begin{array}{c}37 \\
115\end{array}$ & 0.982 \\
\hline Extrathryoid extension & $\begin{array}{l}\text { No } \\
\text { Yes }\end{array}$ & $\begin{array}{c}64 \\
150\end{array}$ & $\begin{array}{l}19 \\
43\end{array}$ & $\begin{array}{c}45 \\
107\end{array}$ & 0.880 \\
\hline Lymphovascular invasion & $\begin{array}{l}\text { No } \\
\text { Yes }\end{array}$ & $\begin{array}{c}43 \\
171\end{array}$ & $\begin{array}{l}15 \\
47\end{array}$ & $\begin{array}{c}28 \\
124\end{array}$ & 0.339 \\
\hline Lymph node metastasis & $\begin{array}{l}\text { No } \\
\text { Yes }\end{array}$ & $\begin{array}{c}79 \\
135\end{array}$ & $\begin{array}{l}32 \\
30\end{array}$ & $\begin{array}{c}47 \\
105\end{array}$ & $0.004^{*}$ \\
\hline Central lymph node metastasis & $\begin{array}{l}\text { No } \\
\text { Yes }\end{array}$ & $\begin{array}{c}79 \\
135\end{array}$ & $\begin{array}{l}32 \\
30\end{array}$ & $\begin{array}{c}47 \\
105\end{array}$ & $0.004^{*}$ \\
\hline Lateral lymph node metastasis & $\begin{array}{l}\text { No } \\
\text { Yes }\end{array}$ & $\begin{array}{c}173 \\
41\end{array}$ & $\begin{array}{c}55 \\
7\end{array}$ & $\begin{array}{c}118 \\
34\end{array}$ & 0.062 \\
\hline Locoregional recurrence & $\begin{array}{l}\text { No } \\
\text { Yes }\end{array}$ & $\begin{array}{c}198 \\
16\end{array}$ & $\begin{array}{c}61 \\
1\end{array}$ & $\begin{array}{c}137 \\
15\end{array}$ & $0.037^{*}$ \\
\hline $\mathrm{BRAF}^{\mathrm{V} 600 \mathrm{E}}$ mutation & $\begin{array}{l}\text { No } \\
\text { Yes }\end{array}$ & $\begin{array}{c}34 \\
180\end{array}$ & $\begin{array}{l}17 \\
45\end{array}$ & $\begin{array}{c}17 \\
135\end{array}$ & $0.003^{*}$ \\
\hline
\end{tabular}

${ }^{*} P<0.05$ between the two categories for a given variable.

\section{Effects of GPR48/LGR4 on thyroid tumor cell growth and migration}

Given the elevated expression of GPR48/LGR4 in thyroid cancer tissue, we investigated the role of GPR48/ LGR4 in proliferation and migration of thyroid cancer cells. We found that GPR48/LGR4 mRNA expression was markedly higher in the thyroid cancer cell lines TPC-1, BCPAP, and 8505C than in Nthy-ori3-1, a normal thyroid follicular cell line derived from a human adult (Figure $2 \mathrm{~A})$. In parallel experiments, we observed that $\mathrm{RSPO} 2$ expression was also higher in the thyroid cancer cell lines $(P<0.001)$ (Figure 2B). Protein expression of GPR48/ LGR4, as determined by Western blot analysis, was also higher in the thyroid cancer cell lines than in Nthyori3-1 (Figure 2C). To assess the effect of GPR48/LGR4 in tumorigenesis of differentiated thyroid carcinoma, we transfected a GPR48/LGR4 expression plasmid into TPC1 and BCPAP, and investigated growth by CCK- 8 viability assay and migration by Transwell assay (Figure 2D-
2K). GPR48/LGR4-overexpressing TPC-1 and BCPAP exhibited significantly elevated cell viability ( $122 \%$ and $117 \%$, respectively) (Figure 2F and 2J). Additionally, the number of migrated cells significantly increased in GPR48/LGR4-overexpressing TPC-1 and BCPAP (138\% and $140.5 \%$, respectively) compared with control (Figure $2 \mathrm{G}$ and $2 \mathrm{~K}$ ).

\section{Inhibition of GPR48/LGR4 blocks thyroid cancer cell proliferation and migration}

To evaluate the effects of GPR48/LGR4 on cancer tumorigenesis, we transfected cells with small interfering RNA oligos (siRNA) targeting GPR48/LGR4 or with scrambled siRNA. Treatment with the targeting siRNA led to a significant reduction of expression of GPR $48 / L G R 4$ in both TPC-1 and BCPAP cells (Figure 3A, 3B, 3E and 3F). GPR 48/LGR4 knockdown significantly decreased the cell viability of TPC- 1 and BCPAP $(80.5 \%$ and $85.2 \%$, respectively) (Figure $3 \mathrm{C}$ and $3 \mathrm{G}$ ). Furthermore, 
Table 3: Multivariate analysis of the relationship between GPR48/LGR4 expression and clinicopathologic factors

\begin{tabular}{lcccc}
\hline Factors & $\mathbf{E x p}(\boldsymbol{\beta})$ & SE & $\mathbf{9 5 . 0 \%}$ CI & P value \\
\hline Tumor size $>1 \mathrm{~cm}$ & 1.384 & 0.329 & $(0.726,2.641)$ & 0.323 \\
Lymph node metastasis & 3.156 & 0.520 & $(1.139,8.747)$ & $0.027^{*}$ \\
Locoregional recurrence & 3.826 & 1.066 & $(0.474,4.918)$ & 0.208 \\
BRAF $^{\mathrm{V} 600 \mathrm{E}}$ mutation & 4.557 & 0.579 & $(1.466,14.162)$ & $0.009^{*}$ \\
\hline
\end{tabular}

$\mathrm{SE}$, standard error; $\operatorname{Exp}(\beta)$, odds ratio; $\mathrm{CI}$, confidence interval.

knockdown of GPR $48 / L G R 4$ significantly decreased the migration of TPC- 1 and BCPAP $(75.2 \%$ and $68.5 \%$, respectively), whereas the scrambled siRNA control had no such effect (Figure 3D and 3H).

\section{GPR48/LGR4 knockdown in thyroid cancer cells downregulates the $\beta$-catenin pathway by preventing activation of MAPK/ERK1/2 signaling}

GPR48/LGR4 activates the $\beta$-catenin signaling pathway and increases expression of its downstream target genes in human cancers $[17,18]$. We investigated whether knockdown of GPR $48 / L G R 4$ decreased $\beta$-catenin signaling in thyroid cancer cells using the luciferasebased TOPflash/FOPflash assay. TCF4 transcription activity decreased $59.0 \%$ in TPC-1 cells and $56.1 \%$ in GPR48/LGR4-knockdown BCPAP cells in comparison with control cells (Figure 4A and $4 \mathrm{~B}$ ). In addition, we monitored expression of $A X I N 2$, a major target gene of $\beta$-catenin, by RT-PCR. The level of AXIN2 mRNA significantly decreased in both TPC-1 cells and GPR48/ LGR4-knockdown BCPAP cells in comparison with control cells (Figure 4C and 4D). Moreover, protein expression levels of the non-phospho (active) $\beta$-catenin were much lower in cells transfected with GPR48/LGR4 siRNA than in controls (Figure $4 \mathrm{E}$ and $4 \mathrm{~F}$ ). These results demonstrate that GPR48/LGR4 activates $\beta$-catenin signaling in differentiated thyroid carcinoma.

GPR48/LGR4 promotes epithelial cell proliferation and migration by activating the ERK and PI3K pathways $[18,23]$. Activation of ERK induces phosphorylation of GSK3 $\beta$ on Ser9, resulting in stabilization of $\beta$-catenin $[24,25]$. To determine the mechanism by which GPR48/ LGR4 promotes thyroid tumorigenesis, we monitored the ERK $1 / 2$ and $\beta$-catenin pathways in GPR48/ $L G R 4$-knockdown thyroid cancer cells. In both TPC1 and BCPAP cells, knockdown of GPR48/LGR4 was associated with reductions in phosphorylation of LRP6, phosphorylation of GSK3 $\beta$ Ser9, and phosphorylation of ERK1/2, whereas total LRP6, total GSK3 $\beta$ and ERK1/2 levels were unchanged (Figure 4E and 4F). These data suggest that GPR48/LGR4 activates MAPK/ERK1/2 in PTC cells. To determine whether the MAPK/ERK1/2 pathway participates in regulation of GPR48/LGR4, we treated cells with pharmacological inhibitors of RAF (sorafenib) or MEK (U0126) and subjected them to immunoblot analysis. Treatment of TPC-1 cells with U0126 markedly decreased the phosphorylation levels of LRP6 and the level of non-phospho (active) $\beta$-catenin. Treatment of BCPAP cells with sorafenib also markedly decreased the expression of GPR48/LGR4 and activation of the $\beta$-catenin pathway (Figure $4 \mathrm{G}$ and $4 \mathrm{H}$ ). Neither inhibitor affected the expression of GPR $48 / L G R 4$ mRNA (Supplementary Figure 2). These results suggest that the MAPK/ERK1/2 pathway is required for GPR48/LGR48mediated $\beta$-catenin signaling, and that post-transcriptional regulation of GPR48/LGR4 in differentiated thyroid carcinoma may be influenced by inhibition of RAF and MEK.

\section{The RSPO2-GPR48/LGR4 signaling axis in PTC}

RSPOs promote activation of the Wnt pathway by binding LGRs $[11,26]$. Based on this premise, we tested whether exogenous RSPO2 could directly increase $\beta$-catenin signaling, using a reporter assay and monitoring AXIN2 expression in control and GPR48/LGR4knockdown thyroid cancer cells. Previous studies report that the functional effects of RSPOs via GPR48/LGR4 are maximal in Wnt3A-conditioned media. Therefore, we harvested cells with Wnt3A-conditioned media and investigated the change in $\beta$-catenin signaling in cancer cells treated with RSPO2 $[11,26]$. TCP-1 and BCPAP cells were treated with RSPO2 (100 ng/mL) for $24 \mathrm{hr}$ after 48 hr transfection with $G P R 48 / L G R 4$-specific or scrambled siRNA. Expression of AXIN2 and TCF4 transcriptional activity increased in both control and GPR48/LGR4knockdown cells after treatment with exogenous RSPO2 (Figure 5A-5D).

To investigate the effect of RSPO 2 on the $\beta$-catenin pathway in relation to GPR48/LGR4, we compared the fold change of $A X I N 2$ and TCF4 transcriptional activity following RSPO2 treatment between GPR48/LGR4knockdown and control cells. Knockdown cells treated with RSPO2 treatment exhibited reductions in the fold change of AXIN2 expression and TCF4 transcriptional activity in comparison with control cells (Figure 5). We 
also investigated the RSPO2-GPR48/LGR4 signaling axis in Nthy-ori3-1 cells, which express lower endogenous levels of RSPO2 than cancer cells. In normal thyroid cells, exogenous RSPO2 treatment also induced activation of the $\beta$-catenin signaling pathway (Supplementary Figure 3 ). These findings suggest that the RSPO2-GPR48/ LGR4 signaling axis may be important in normal thyroid physiology, as well as in thyroid tumorigenesis.

To investigate the regulation of ERK $1 / 2$ phosphorylation by RSPO2-GPR48/LGR4 signaling axis, we monitored ERK1/2 phosphorylation in GPR48/ LGR4-knockdown and control cells treated with exogenous RSPO2. ERK1/2 phosphorylation significantly increased in control BCPAP and TPC1 cells upon RSPO2 treatment (Figure 5E, and 5F), but not in GPR48/LGR4knockdown cells. Based on these findings, we speculate that exogenous RSPO2 treatment can induce increased ERK1/2 phosphorylation in thyroid cancer cells, and that the effect of RSPO2 is strongly dependent on expression of GPR48/LGR4.

\section{DISCUSSION}

In this study, we obtained clear evidence of the functional expression of GPR48/LGR4 in thyroid cancer cells in vitro and in vivo. Furthermore, we found that RSPO2, a ligand of GPR48/LGR4, was expressed at higher levels in PTC, and that it activated $\beta$-catenin signaling via

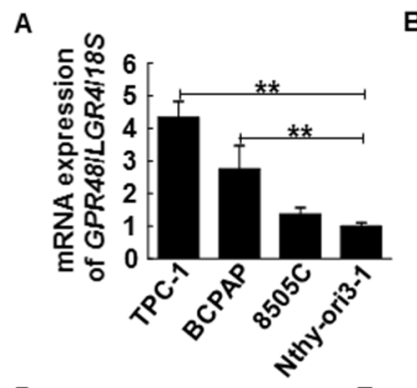

D

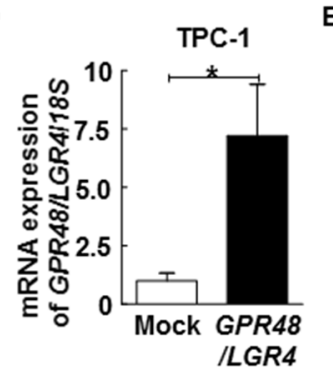

"



B

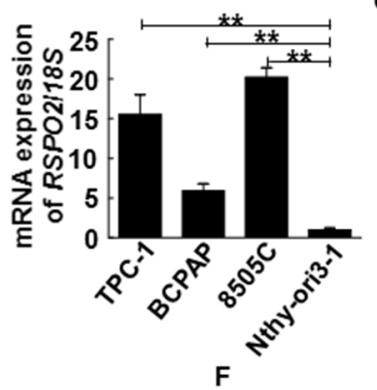

C
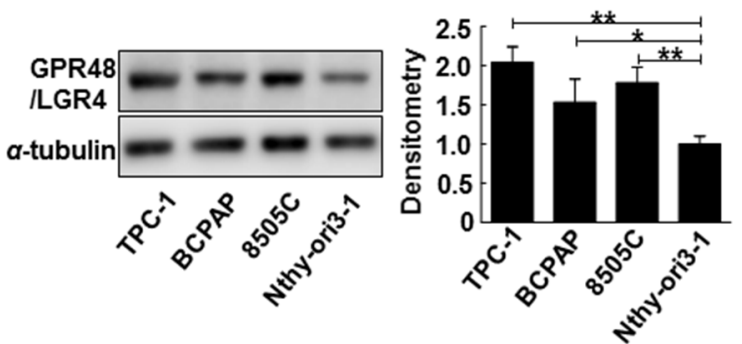

G
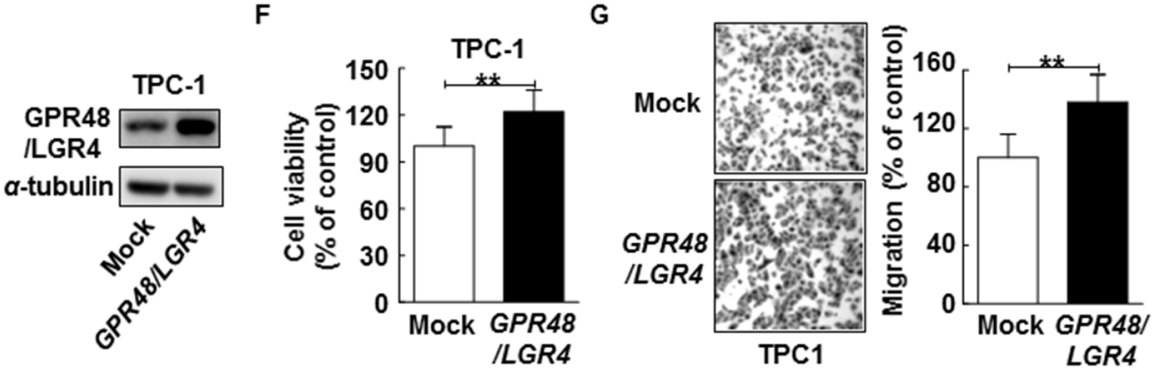

$J$

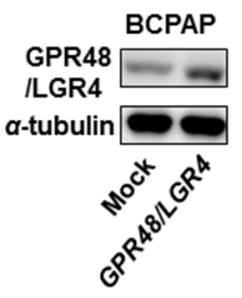

K

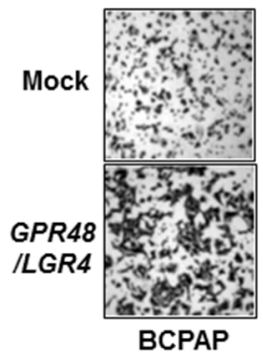



Figure 2: Effect of GPR48/LGR4 on viability and migration of differentiated thyroid carcinoma cells. (A) $G P R 48 / L G R 4$ mRNA levels in thyroid carcinoma cell lines. (B) RSPO2 mRNA levels in thyroid carcinoma cell lines. (C) Representative images of immunoblot analysis for detection of GPR48/LGR4 in thyroid carcinoma cell lines. (D) TPC-1 cells were transiently transfected with $G P R 48 / L G R 4$ or mock cDNA. (E) Representative images of immunoblot analysis for detection of of GPR48/LGR4 in TPC-1 cells transfected with $G P R 48 / L G R 4$ or mock cDNA. (F) Effect of GPR48/LGR4 on cell viability in TPC-1 cells transfected with GPR48/LGR4 cDNA or empty vector, as determined by CCK-8 assay. (G) Effect of GPR48/LGR4 on migration in TPC-1 cells transfected with GPR48/LGR4 cDNA or empty vector, as determined by Transwell chamber assay. (H) BCPAP cells transiently were transfected with $G P R 48 / L G R 4$ or mock cDNA. (I) Representative images of immunoblot analysis for detection of GPR48/LGR4 in BCPAP cells transfected with GPR48/LGR4 or mock cDNA. (J) Effect of GPR48/LGR4 on cell viability of BCPAP cells transfected with $G P R 48 / L G R 4$ cDNA or empty vector, as determined by CCK-8 assay. (K) Effect of GPR48/LGR4 on migration in BCPAP cells transfected with GPR48/LGR4 cDNA or empty vector, as determined by Transwell chamber assay. Each figure is representative of three independent experiments performed in triplicate. 'Mock' indicates cells that were transfected with an empty vector. ${ }^{*}, P<0.05 ;{ }^{* *}, P<0.01$. 
GPR48/LGR4. These observations suggest that elevated activity of the RSPO2-GPR48/LGR4 signaling axis in tumor cells determines the behaviors of thyroid cancers. This idea is further supported by the elevated viability and migration of tumor cells expressing higher levels of GPR48/LGR4. More importantly, the clinical observations revealed that patients with higher expression of GPR48/ LGR4 tended to experience more rapid regional tumor progression, including metastasis. These findings provide the first evidence that the RSPO2-GPR48/LGR4 pathway is hyperactivated in thyroid cancer, particularly PTC, and acts as a tumor-promoting factor.

LGRs were originally identified in in silico screens for cDNAs encoding proteins with homology to the glycoprotein hormone receptor class of G-proteincoupled receptors (GPRs) such as TSH [5, 6, 27]. Early studies showed that GPR48/LGR4 and GPR49/LGR5 are closely related, as reflected by the similarities in their amino acid sequences; however, GPR48/LGR4 is the only transcript found in rodent thyroid gland [7]. In this study, we obtained consistent results in human thyroid gland, which exhibited focal and low levels of GPR48/ LGR4 expression. Recent efforts elucidated the role of
GPR48/LGR4 and GPR49/LGR5 by demonstrating that these receptors are the signaling platform for epithelial stem cells $[28,29]$. Although we detected focal and low levels of GPR48/LGR4 expression, the functional role of this factor in epithelial homeostasis in adult thyroid gland remains to be determined.

Recently, several groups revealed that the RSPOs, which are secreted Wnt agonists, are the endogenous ligands of GPR48/LGR4 and GPR49/LGR5, revealing the crucial role of LGR proteins in epithelial stem cell homeostasis in the intestines [11, 26, 30, 31]. Subsequent studies revealed that the RSPO-GPR48/LGR4 and GPR49/LGR5 ligand receptor system constitute a major axis involved in regulation of Wnt signaling, reflected by its pleiotropic roles in development, survival of adult stem cells, and carcinogenesis [11,32]. More recent work showed that RSPOs potentiate $\mathrm{Wnt} / \beta$-catenin signaling through GPR48/LGR4 [26, 31, 33]. In the presence of RSPOs and LGR receptors, the Frizzled receptor is activated, leading to repression of GSK $3 \beta$, accumulation of active $\beta$-catenin, and its translocation to the nucleus [34]. Additionally, multiple studies demonstrated that in the context of tumorigenesis, GPR48/LGR4 activates
A

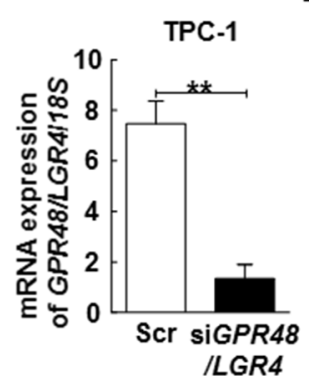

E

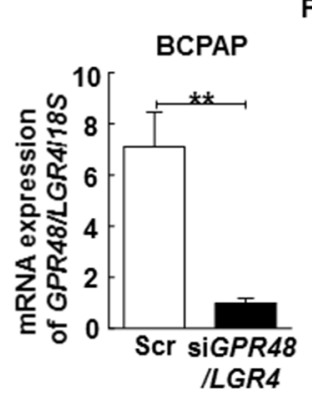

B

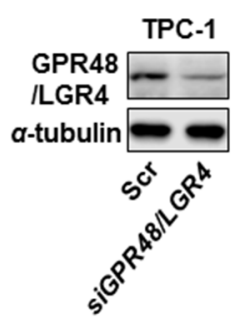

F

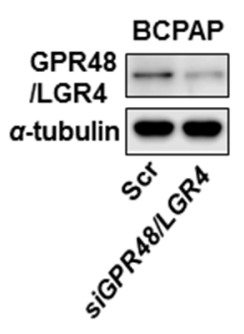

C

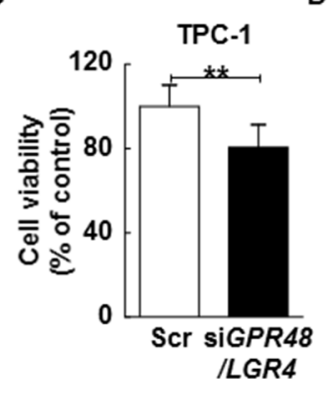

G



D
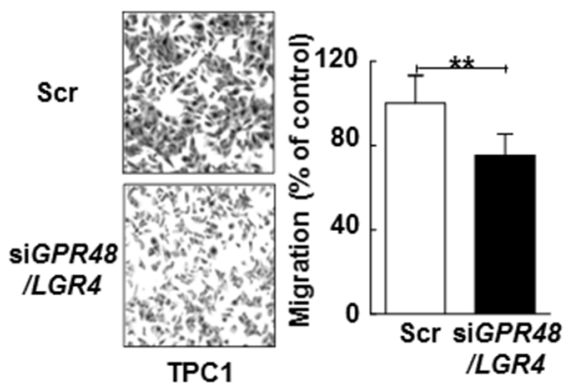

$\mathrm{H}$
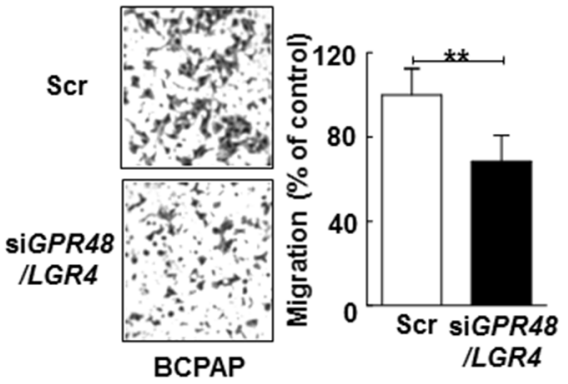

Figure 3: Inhibition of GPR48/LGR4 decreases proliferation and migration of differentiated thyroid carcinoma cells. (A) TPC-1 cells transiently transfected with GPR48/LGR4-specific or scrambled siRNA. (B) Representative images of immunoblot analysis for detection of GPR48/LGR4 in TPC-1 cells transfected with GPR48/LGR4-specific or scrambled siRNA. (C) Effect of GPR48/LGR4 on cell viability in TPC-1 cells transfected with $G P R 48 / L G R 4$-specific or scrambled siRNA, as determined by CCK-8 assay. (D) Effect of GPR48/LGR4 on migration in TPC-1 cells transfected with GPR48/LGR4-specific or scrambled siRNA, as determined by Transwell chamber assay. (E) BCPAP cells were transiently transfected with $G P R 48 / L G R 4$-specific or scrambled siRNA. (F) Representative images of immunoblot analysis for detection of GPR48/LGR4 in BCPAP cells transfected with GPR48/LGR4-specific or scrambled siRNA. (G) Effect of GPR48/LGR4 on cell viability in BCPAP cells transfected with GPR48/LGR4-specific or scrambled siRNA, as determined by CCK-8 assay. (H) Effect of GPR48/LGR4 in BCPAP cells transfected with GPR48/LGR4-specific or scrambled siRNA, as determined by Transwell chamber assay. 'Scr' indicates cells that were transfected with a scrambled siRNA. ${ }^{*}, P<0.05 ;{ }^{* *}, P<0.01$. 
Wnt/ $\beta$-catenin signaling via the AKT and ERK pathway. In response to certain growth stimuli and oncogenes, activated AKT and ERK1/2 can phosphorylate Ser9 of GSK3 $\beta$, resulting in activation of Wnt $/ \beta$-catenin signaling during tumorigenesis $[24,25]$. Overexpression of GPR48/ LGR4 increases phosphorylation levels of AKT and ERK1/2, and GPR48/LGR4 activates Wnt/ $\beta$-catenin signaling via a PI3K- and ERK1/2-dependent mechanism in colon carcinogenesis [16, 17]. Furthermore, inhibition of GPR48/LGR4 is associated with downregulation of AKT and the mTOR signaling pathway in prostate tumorigenesis [18]. To date, however, few studies have investigated the function of RSPOs and GPR48/LGR4 in thyroid tumorigenesis.
Aberrant activation of $\mathrm{Wnt} / \beta$-catenin signaling is strongly associated with thyroid tumorigenesis [35]. Previous studies reported expression of components of the Wnt signaling pathway, including Wnt factors, members of the Frizzled receptor family, and Disheveled isoforms, in human thyroid cells [36]. In addition, these studies revealed the existence of a degradation complex consisting of APC, Axin, and GSK3 $\beta$ in human thyroid cells. In the context of thyroid tumorigenesis, Ishigaki et al., reported that $\beta$-catenin levels in human PTC are significantly correlated with cyclin D1 expression [35]. Recent studies report that inhibition of $\beta$-catenin diminishes tumorigenesis of differentiated thyroid cancer [19, 37]. In addition, the proto-oncogene RET/PTC induces

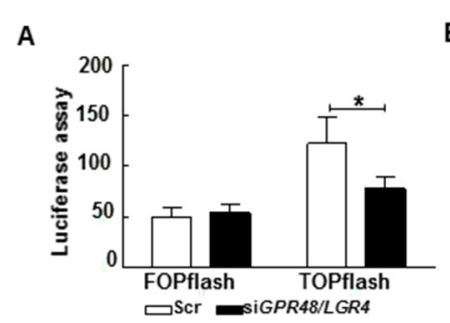

E

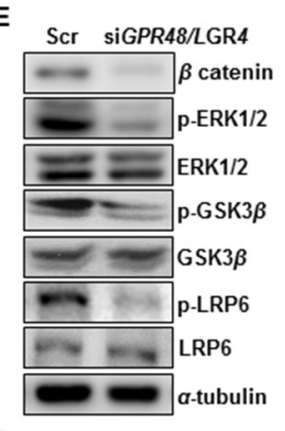

G

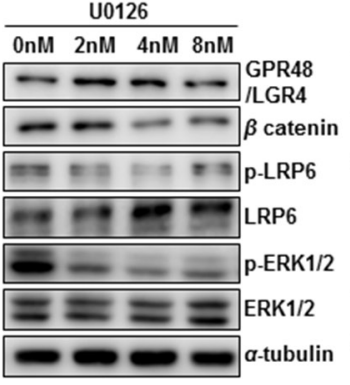

B
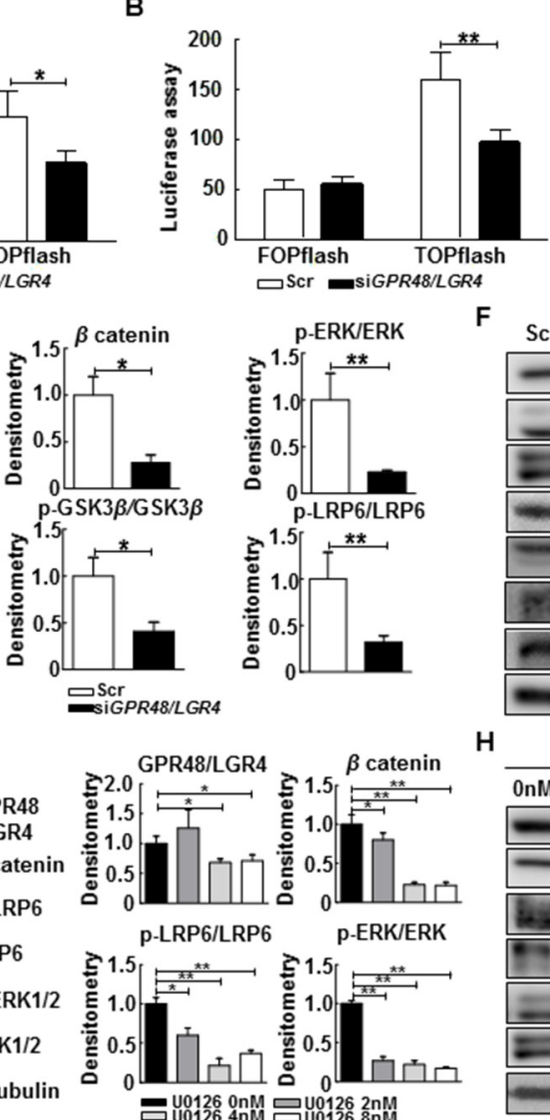

$\mathrm{H}$



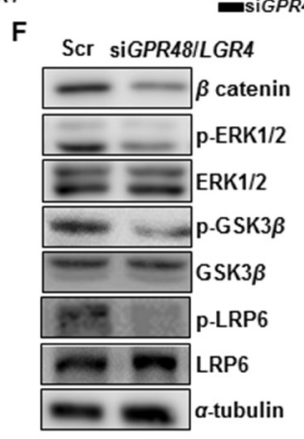


Figure 4: Regulation of the $\beta$-catenin pathway by GPR48/LGR4 via MAPK/ERK1/2 pathway. (A) Effect of downregulation of GPR48/LGR4 on $\beta$-catenin signaling in TPC-1 using the luciferase-based TOPflash/FOPflash assay. (B) Effect of downregulation of GPR48/LGR4 on $\beta$-catenin signaling in BCPAP using the luciferase-based TOPflash/FOPflash assay. (C) AXIN2 mRNA levels in TPC-1 cells transfected with GPR48/LGR4-specific or scrambled siRNA (D) AXIN2 mRNA levels in BCPAP cells transfected with GPR48/LGR4specific or scrambled siRNA. (E) Representative images of immunoblot analysis for detection of non-phospho $\beta$-catenin, phosphoERK1/2, ERK1/2, phospho-GSK3 $\beta$, GSK3 $\beta$, phospho-LRP6, LRP6, and $\alpha$-tubulin in TPC-1 cells transfected with GPR48/LGR4-specific or scrambled siRNA. (F) Representative images of immunoblot analysis for detection of of non-phospho $\beta$-catenin, phospho-ERK1/2, ERK1/2, phospho-GSK3 $\beta$, GSK3 $\beta$, phospho-LRP6, LRP6 and $\alpha$-tubulin in BCPAP cells transfected with GPR48/LGR4-specific or scrambled siRNA. (G) Representative images of immunoblot analysis for detection of GPR48/LGR4, non-phospho $\beta$-catenin, phosphoLRP6, LRP6, phospho-ERK1/2, ERK1/2, and $\alpha$-tubulin in TPC-1 cells treated with U0126 (MEK inhibitor). $\alpha$-tubulin was used as a loading control. (H) Representative images of immunoblot analysis for detection of GPR48/LGR4, non-phospho $\beta$-catenin, phospho-LRP6, LRP6, phospho-ERK1/2, ERK1/2, and $\alpha$-tubulin in BCPAP cells treated with sorafenib (RAF inhibitor). $\alpha$-tubulin was used as a loading control. 'Scr' indicates cells transfected with scrambled siRNA. ", $P<0.05$; ${ }^{* *}, P<0.01$. 
nuclear accumulation of $\beta$-catenin in PTC by activating the PI3K/AKT and MAPK signaling pathways, but the precise mechanism underlying $\beta$-catenin dysregulation in differentiated thyroid carcinoma remains unknown [38, 39].

We detected an association between GPR48/LGR4 expression and diverse clinicopathologic findings in PTC, and also observed a significant association between GPR48/LGR4 expression and the presence of the BRAF mutation in multivariate analysis. Knockdown of GPR48/ $L G R 4$ in tumor cells was significantly associated with reduced phosphorylation of Ser9 of GSK $3 \beta$ and ERK1/2, resulting in downregulation of $\beta$-catenin signaling. Elucidation of the precise mechanism by which GPR48/ LGR4 influences the ERK pathway will require additional experiments, e.g., immunoprecipitations and enzymatic binding assays.

Collectively, our observations support the idea that aberrant increase of GPR48/LGR4- $\beta$-catenin pathway promotes thyroid tumorigenesis through the RAF-RAS pathway. Consistent with this, administration of RSPO1 to mice increases cell size in the small intestine, and RSPO fusions occur in colon and lung cancer [40-41], [32]. In this study, we demonstrated that exogenous RSPO2 treatment increased GPR48/LGR4-dependent ERK activation in thyroid cancer cells.

Accordingly, our results suggest that GPR48/ LGR4 protein is worth studying as a new therapeutic target in PTC. Notably in this regard, a recent study reported an association between GPR49/LGR5 and human PTC aggressiveness [42]. Overexpression of LGR5 in human PTC is associated with several markers of tumor aggressiveness and predicted LN metastasis. Consistent with this, we observed that GPR49/LGR5 was overexpressed in thyroid tumor tissue relative to normal tissue, although there was no significant association between GPR49/LGR5 and clinicopathologic parameters (Supplementary Table 1).

In summary, we showed that the RSPO2 and GPR48/LGR4 function in thyroid tumorigenesis, particularly in patients with regional tumor progression including LN metastasis. These effects may involve the intrinsic stimulatory role of the RSPO2-GPR48/LGR4 signaling axis on proliferation and migration of thyroid
A

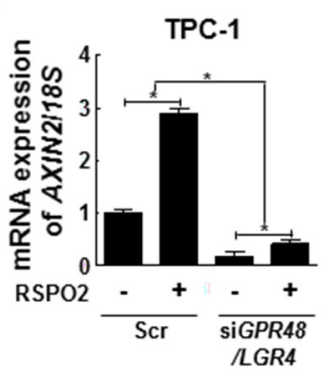

E

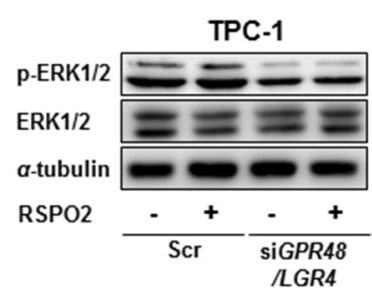

B
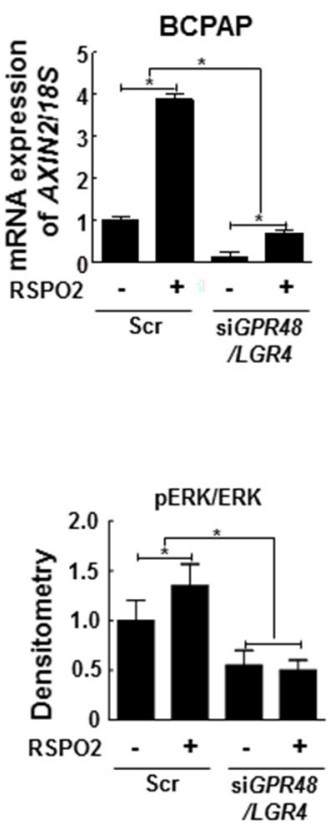

C
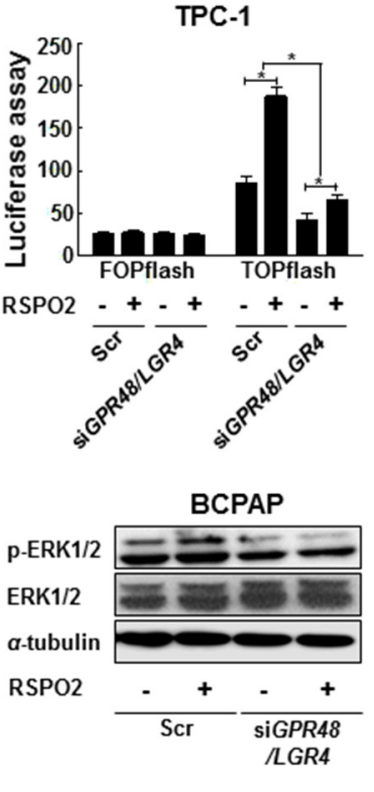

D
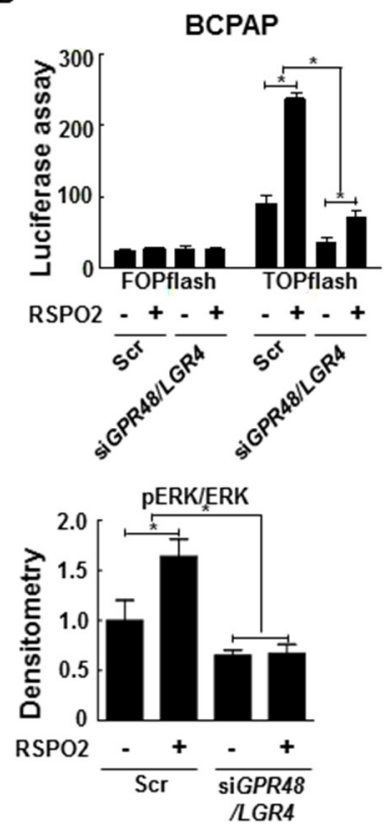

Figure 5: RSPO2-GPR48/LGR4 signaling axis in papillary thyroid carcinoma. (A) AXIN2 mRNA levels in TPC-1 cells treated with RSPO2 (100 ng/mL) for $24 \mathrm{hr}$ after transfection with GPR48/LGR4-specific or scrambled siRNA. (B) AXIN2 mRNA levels in BCPAP cells treated with RSPO2 $(100 \mathrm{ng} / \mathrm{ml})$ for $24 \mathrm{hr}$ after transfection with $G P R 48 / L G R 4$-specific or scrambled siRNA. (C) $\beta$-catenin signaling in TPC-1 cells transfected with Gpr48/Lgr4-specific or scrambled siRNA in response to treatment with RSPO2 (100 ng/mL), as determined by the luciferase-based TOPflash/FOPflash assay. (D) $\beta$-catenin signaling in BCPAP cells transfected with GPR48/LGR4specific or scrambled siRNA in response to treatment with RSPO2 $(100 \mathrm{ng} / \mathrm{mL})$, as determined by the luciferase-based TOPflash/FOPflash assay. (E) Representative images of immunoblot analysis for detection of ERK1/2, phospho-ERK1/2, and $\alpha$-tubulin in TPC-1 cells treated with RSPO2 $(100 \mathrm{ng} / \mathrm{mL})$ for $24 \mathrm{hr}$ after transfection with $G P R 48 / L G R 4$-specific or scrambled siRNA. $\alpha$-tubulin was used as a loading control. (F) Representative images of immunoblot analysis for detection of ERK1/2, phospho-ERK1/2, and $\alpha$-tubulin in BCPAP cells treated with RSPO2 $(100 \mathrm{ng} / \mathrm{mL})$ for $24 \mathrm{hr}$ after transfection with $G P R 48 / L G R 4$-specific or scrambled siRNA. $\alpha$-tubulin was used as a loading control. 'Scr' indicates cells transfected with scrambled siRNA. * $P<0.05$. 
cancer cells. Our findings suggest that GPR48/LGR4 represents a novel target for treating differentiated thyroid carcinoma by modulating the $\beta$-catenin pathway.

\section{MATERIALS AND METHODS}

\section{Patients and tissue samples}

Data were retrospectively analyzed from 214 patients with PTC who underwent total thyroidectomy and cervical LN dissection at Chungnam National University Hospital from 2003 to 2010. Prophylactic central LN dissection was performed in 148 patients without clinical evidence of positive LN on imaging or palpation. Twenty-five patients with clinically evident positive central $\mathrm{LN}$ underwent therapeutic central $\mathrm{LN}$ dissection. The remaining 41 patients underwent central and lateral $\mathrm{LN}$ dissection due to evidence of metastatic $\mathrm{LN}$ in the lateral neck before surgery. Lateral LN dissection was performed using a modified radical operation that involved complete removal of level II-V lateral cervical LNs. Level I dissection was not performed without clinical evidence of metastases at level I. Patients who underwent lobectomy only, but not central LN dissection, or whose medical record was unclear, were excluded from the study. All specimens were collected from patients after informed consent was obtained in accordance with the institutional guidelines of Chungnam National University Hospital. Diagnosis was made according to the World Health Organization classification of endocrine organ tumors [43]. Surveillance for recurrent disease usually consisted of physical examination, serum thyroglobulin ( $\mathrm{Tg}$ ) level, and ultrasonography every 12 months for up to 5 years, and patients were followed for a mean duration of $86.6 \pm$ 22.5 months to evaluate tumor recurrence [44].

\section{Immunohistochemistry}

Tissues were retrieved from the archives of the Department of Pathology, Chungnam National University Hospital, South Korea. Before immunohistochemistry, 4-micron-thick sections of paraffin-embedded tissue blocks were incubated at $56^{\circ} \mathrm{C}$ for $3 \mathrm{hr}$. Specimens were stained using the Vectastain ABC HRP kit (Vector Laboratories, Inc., Burlingame, CA, USA). Antigen retrieval was performed by microwaving in citrate buffer for 10 minutes. Endogenous peroxidase activity was inactivated by incubation in 3\% hydrogen peroxide for 10 minutes. Non-specific binding sites were blocked by incubation in $10 \%$ normal goat serum in phosphatebuffered saline (PBS). Tissue section slides were incubated for $1 \mathrm{hr}$ at room temperature with primary antibodies against GPR48/LGR4 (1:50, Atlas Antibodies, Stockholm, Sweden) and BRAF ${ }^{\mathrm{V} 600 \mathrm{E}}$ (Beecher Instruments, Silver Spring, Maryland) as described [45, 46]. Tissue sections were counterstained with hematoxylin. Negative controls were incubated with PBS instead of primary antibody, and no positive staining was observed. In addition, positive controls were performed with sections of colon adenocarcinoma and stained for GPR48/LGR4. Tissue slides were analyzed on an OLYMPUS BX51 microscope. Microscopic analysis was performed by two certified pathologists who were unaware of the identity of the samples and the corresponding clinicopathologic data. To quantify GPR48/LGR4 and BRAF ${ }^{\mathrm{V} 600 \mathrm{E}}$ IHC staining, a scoring system was used that combined the intensity and distribution of positive staining: 0 , no staining; +1 , weak staining in focal tumor areas; +2 , moderate staining in most tumors; and +3 , strong staining in most tumors. Finally, for statistical comparison, tissue slides with scores of $0,+1$, or +2 were included in the low-GPR48/LGR4 immunoexpression group, and those with a score of +3 were included in the high-GPR48/ LGR4 immunoexpression group. Specimens with no staining for $\mathrm{BRAF}^{\mathrm{V} 600 \mathrm{E}}$ were classified as lacking the $\mathrm{BRAF}^{\mathrm{V} 600 \mathrm{E}}$ mutation, and those with scores of $+1,+2$, or +3 for $\mathrm{BRAF}^{\mathrm{V} 600 \mathrm{E}}$ immunoexpression were classified as having the $\mathrm{BRAF}^{\mathrm{V}}{ }^{600}$ mutation.

\section{Cell lines}

The human anaplastic thyroid cancer cell line, 8505C, was purchased from DSMZ (Braunschweig, Germany). Nthy-ori 3-1, a normal thyroid follicular cell line from human adult, was obtained from Dr. Anna Maria Porcelli (Bologna University, Bologna, Italy). The human PTC cell lines BCPAP and TPC-1 were provided by Dr. M. Santoro (Università di Napoli Federico II, Naples, Italy) and Dr. Masahide Takahashi (Nagoya University, Nagoya, Japan), respectively.

\section{Cell culture and transfection}

BCPAP and TPC-1 were maintained in Dulbecco's Modified Eagle's Medium (DMEM; Invitrogen) [47-49]. Nthy-ori3-1 and 8505C were cultured in RPMI 1640. Both types of media were supplemented with $10 \%$ heat-inactivated fetal bovine serum (FBS), $100 \mathrm{U} / \mathrm{mL}$ penicillin, and $100 \mu \mathrm{g} / \mathrm{mL}$ streptomycin [47, 48]. Cells were cultured at $37^{\circ} \mathrm{C}$ in a humidified chamber under a $5 \% \mathrm{CO}_{2}$ atmosphere. Transient transfection was performed using the Lipofectamine 2000 reagent (Invitrogen, Carlsbad, CA, USA) when cells reached $60 \%$ confluence. The full-length cDNA encoding human GPR48/LGR4 was PCR-amplified from a cDNA library and inserted into the pCMV6-Entry (cat \#PS100001) vector purchased from OriGene (Rockville, MD, USA). TPC-1 and BCPAP cells were transfected with 20 pmol Stealth siRNA or siGPR48/ LGR4 (Invitrogen, Carlsbad, CA, USA) oligomers in $50 \mu \mathrm{L}$ Opti-MEM I using Lipofectamine RNAiMAX (Invitrogen, Carlsbad, CA, USA). All experiments were performed in duplicate and repeated at least three times. 


\section{Recombinant human RSPO2 treatment in human thyroid cell lines}

The immortalized normal thyroid cell line, Nthyori3-1, and thyroid cancer cell lines BCPAP and TPC-1 were treated with recombinant human RSPO2 (RSPO2, R\&D Systems, 3266-RS-025). Recombinant RSPO2 was diluted to $100 \mu \mathrm{g} / \mathrm{mL}$ in PBS containing $0.1 \%$ bovine serum albumin. Human cell lines were treated with RSPO2 at $100 \mathrm{ng} / \mathrm{mL}$, harvested after $24 \mathrm{hr}$ in Wnt3Aconditioned media, and then processed for mRNA, protein, and luciferase assays. To exclude the effect of bovine serum albumin, control cells were treated with $0.1 \%$ bovine serum albumin.

\section{Total RNA isolation and quantitative real-time reverse transcriptase-polymerase chain reaction (RT-PCR)}

Total RNA was isolated using Trizol (Invitrogen, Carlsbad, CA, USA). cDNA was prepared from total RNA using M-MLV Reverse Transcriptase and oligodT primers (Invitrogen, Carlsbad, CA, USA). Real-time PCR was performed using cDNA, QuantiTect SYBR Green PCR Master Mix (QIAGEN), and specific primers (Supplementary Table 2). PCR conditions were as follows: 40 cycles of $95^{\circ} \mathrm{C}$ for 15 seconds, $60^{\circ} \mathrm{C}$ for 1 minute, and $72^{\circ} \mathrm{C}$ for 1 minute $[47,48,50,51]$.

\section{Western blot analysis}

Cells were washed twice in ice-cold PBS. Wholecell protein extracts were obtained by lysis with sodium dodecyl sulfate-polyacrylamide gel electrophoresis (SDS-PAGE) sample buffer [62.5mMTris-HCl (PH 6.8), $2 \%$ SDS, 10\% glycerol, $50 \mathrm{mM}$ dithiothreitol (DTT), $0.01 \%$ bromophenol blue, protease inhibitors]. Protein concentrations in cell lysates were measured using the Bradford reagent (Bio-Rad). Prior to loading, samples were denatured by boiling for 10 minutes, and then separated by SDS-PAGE on $5-10 \%$ gels. Resolved proteins were transferred to nitrocellulose (NC) (Amersham Biosciences, Germany) or polyvinylidene difluoride (PVDF) membrane (Thermo Fisher Scientific, USA). The membranes were blocked for $2 \mathrm{hr}$ in Tris-buffered saline (TBS) containing $0.1 \%$ Tween 20 (Sigma Aldrich) and 3\% BSA. The blots were then incubated overnight at $4{ }^{\circ} \mathrm{C}$ with primary antibodies against GPR48/LGR4 (Abcam), GAPDH (Cell Signaling Technology), ERK (Cell Signaling Technology), phospho-ERK (Cell Signaling Technology), GSK3 $\beta$ (Cell Signaling Technology), phospho-GSK3 $\beta$ (Cell Signaling Technology), non-phospho $\beta$-catenin (Cell Signaling Technology), phospho-LRP6 (Cell Signaling Technology), LRP6 (Cell Signaling Technology), and $\alpha$-tubulin (Abcam). The blots were washed three times for 10 minutes each with TBS containing $0.1 \%$ Tween-20.
Immunoreactive bands were developed using peroxidaseconjugated secondary antibodies (Phototope-HRP Western Blot Detection Kit; New England Biolabs, Beverly, MA, USA).

\section{Cell viability assay}

The cells were seeded at $5.0 \times 10^{3}$ cells $/ \mathrm{mL}$ in 96 well microplates and allowed to attach for $24 \mathrm{hr}$. After transfection with control, GPR $48 / L G R 4$ cDNA, siRNA, siGPR $48 / L G R 4$ for $48 \mathrm{hr}$, cell viability was assessed using the Cell Counting Kit-8 (CCK-8, Dojindo Molecular Technologies, Maryland, USA). Briefly, the highly water-soluble tetrazolium salt WST-8 [2-(2-methoxy-4nitrophenyl)-3-(4-nitrophenyl)-5-(2, 4-disulfophenyl)$2 \mathrm{H}$-tetrazolium, monosodium salt] produces an orangecolored water-soluble product, formazan. The amount of formazan dye generated by dehydrogenases in cells is directly proportional to the number of living cells. CCK-8 $(10 \mathrm{~mL})$ was added to each well and incubated for $3 \mathrm{hr}$ at $37^{\circ} \mathrm{C}$, and then cell viability was assessed by measuring absorbance at $450 \mathrm{~nm}$ on a microplate reader. Three replicate wells were used for each experimental condition.

\section{Cell migration assay}

Migration of PTC cells was performed using Transwell chambers (Corning Costar, Cambridge, MA) with polycarbonate filters $6.5 \mathrm{~mm}$ in diameter $(8 \mu \mathrm{m}$ pore size). For the migration assay, the lower surface of the filter was coated with $10 \mu \mathrm{g}$ of gelatin, and fresh medium containing 5\% FBS was placed in the lower wells. PTC cells (BCPAP or TPC-1) were transfected with cDNA or siRNA for $48 \mathrm{hr}$, incubated for $24 \mathrm{hr}$ in medium containing $1 \%$ FBS, trypsinized, and suspended at a final concentration of $1 \times 10^{6}$ cells $/ \mathrm{mL}$ in medium containing $1 \%$ FBS. Cell suspension $(100 \mu \mathrm{L})$ was loaded into each of the upper wells, and the chambers were incubated at $37^{\circ} \mathrm{C}$ for $6 \mathrm{hr}$. Cells were fixed and stained with crystal violet. Non-migrating cells on the upper surface of the filter were removed by wiping with a cotton swab. Chemotaxis was quantified by counting the cells that migrated to the lower side of the filter, using an optical microscope (200×); eight randomly chosen fields were counted for each migration assay [52].

\section{TOPflash/FOPflash luciferase assay}

To assess $\beta$-catenin activity induced by GPR48/ LGR4, thyroid cancer cells (BCPAP and TPC-1) were treated with si-GPR48/LGR4 or si-control for $48 \mathrm{hr}$, and then transiently transfected for $24 \mathrm{hr}$ with TOPflash and FOPflash plasmids $(2 \mu \mathrm{g}$ each) provided by Dr. DaeSik Lim (KAIST, Korea) using Lipofectamine Plus (Invitrogen) and OptiMEM (Invitrogen). Luciferase levels were determined using a luciferase assay kit (Promega). For each sample, the TOPflash reporter 
activity is presented as the relative ratio of normalized against Renilla luciferase activity. All experiments were performed in triplicate.

\section{Statistical analysis}

Results are shown as means \pm standard deviation (SD). Fisher's exact test and two-tailed t-test were used to compare patients' clinicopathologic data. Patients were divided into two groups, high- and low-immunostaining, according to GPR48/LGR4 expression as described above. Group comparisons of categorical variables were performed by linear-by-linear association and multivariate analysis using a stepwise logistic. All in vitro experiments were repeated three times, and statistical significance was analyzed using two-tailed Student's t-test or one-way analysis of variance (ANOVA) followed by Tukey's post hoc test. Data are presented as means $\pm \mathrm{SD}$, and a $P$ value $<0.05$ was considered statistically significant $\left({ }^{*} P<0.05\right.$; ${ }^{* *} P<0.01$ ). The SPSS software (Version 20) was used for all statistical analyses.

\section{Abbreviations}

GPCR: G-protein coupled receptor; LGR: leucinerich repeat-containing G-protein-coupled receptor; GPR48: G-protein coupled receptor 48; RSPO: R-spondin; LRP6: Low-density lipoprotein receptor-related protein 6; P27 ${ }^{\text {kipl }}$ : Cyclin-dependent kinase inhibitor 1B; TCF4: $\mathrm{T}$ cell transcription factor 4; $\mathrm{PI} 3 \mathrm{~K}$ : phosphoinositide 3-kinase; AKT: protein kinase B PTC: papillary thyroid carcinoma; SCNs: solid cell nests; Nkx2.1: NK2 homeobox 1; RT-PCR: reverse transcription polymerase chain reaction; US: ultrasonography; FNAB: fine needle aspiration biopsy; LN: lymph node; GSK3 $\beta$ : glycogen synthase kinase 3 beta; ERK1/2: extracellular signalregulated kinases; $1 / 2$ TSH: thyroid-stimulating hormone; APC: adenomatous polyposis coli.

\section{Author contributions}

Conceived and designed the experiments: YEK KKS MS. Performed the experiments: YEK JMK MJ SY JTK. Analyzed the data: MJC SKK SEL KL. Contributed reagents/materials/analysis tools: JL BSK HWK. Wrote the paper: YEK HY JMK JYC MS.

\section{ACKNOWLEDGMENTS}

This research was supported by the National Research Foundation of Korea (NRF) funded by the Ministry of Science, ICT \& Future Planning (NRF2015R1A2A1A13000951, NRF-2015R1D1A1A01060529, and NRF-2017R1D1A1B03027820). JMK was supported by a grant from the Korean Health Technology R\&D Project, Ministry of Health \& Welfare (HI15C0789). SY, HWK, JTK, MJC, and SKK were supported by BK21 Plus project of the National Research Foundation of Korea. MS and KKS were supported by research funding (2014) from Chungnam National University, Republic of Korea.

\section{CONFLICTS OF INTEREST}

The authors declare no conflicts of interest.

\section{REFERENCES}

1. Vassart G, Dumont JE. The thyrotropin receptor and the regulation of thyrocyte function and growth. Endocr Rev. 1992; 13:596-611.

2. Barker N, Tan S, Clevers H. Lgr proteins in epithelial stem cell biology. Development. 2013; 140:2484-94. https://doi. org/10.1242/dev.083113.

3. Leushacke M, Barker N. Lgr5 and Lgr6 as markers to study adult stem cell roles in self-renewal and cancer. Oncogene. 2012; 31:3009-22. https://doi.org/10.1038/onc.2011.479.

4. Barker N, Clevers H. Leucine-rich repeat-containing G-protein-coupled receptors as markers of adult stem cells. Gastroenterology. 2010; 138:1681-96. https://doi. org/10.1053/j.gastro.2010.03.002.

5. Hsu SY, Liang SG, Hsueh AJ. Characterization of two LGR genes homologous to gonadotropin and thyrotropin receptors with extracellular leucine-rich repeats and a $\mathrm{G}$ protein-coupled, seven-transmembrane region. Mol Endocrinol. 1998; 12:1830-45. https://doi.org/10.1210/ mend.12.12.0211.

6. Hsu SY, Kudo M, Chen T, Nakabayashi K, Bhalla A, van der Spek PJ, van Duin M, Hsueh AJ. The three subfamilies of leucine-rich repeat-containing $G$ protein-coupled receptors (LGR): identification of LGR6 and LGR7 and the signaling mechanism for LGR7. Mol Endocrinol. 2000; 14:1257-71. https://doi.org/10.1210/mend.14.8.0510.

7. Van Schoore G, Mendive F, Pochet R, Vassart G. Expression pattern of the orphan receptor LGR4/GPR48 gene in the mouse. Histochem Cell Biol. 2005; 124:35-50. https://doi. org/10.1007/s00418-005-0002-3.

8. Blaydon DC, Ishii Y, O'Toole EA, Unsworth HC, Teh MT, Rüschendorf F, Sinclair C, Hopsu-Havu VK, Tidman N, Moss C, Watson R, de Berker D, Wajid M, et al. The gene encoding R-spondin 4 (RSPO4), a secreted protein implicated in Wnt signaling, is mutated in inherited anonychia. Nat Genet. 2006; 38:1245-47. https://doi.org/10.1038/ng1883.

9. Kazanskaya O, Glinka A, del Barco Barrantes I, Stannek $\mathrm{P}, \mathrm{Niehrs} \mathrm{C}, \mathrm{Wu} \mathrm{W}$. R-Spondin2 is a secreted activator of $\mathrm{Wnt} / \beta$-catenin signaling and is required for Xenopus myogenesis. Dev Cell. 2004; 7:525-34. https://doi. org/10.1016/j.devcel.2004.07.019.

10. de Lau WB, Snel B, Clevers HC. The R-spondin protein family. Genome Biol. 2012; 13:242. https://doi.org/10.1186/ gb-2012-13-3-242.

11. Carmon KS, Gong X, Lin Q, Thomas A, Liu Q. R-spondins function as ligands of the orphan receptors LGR4 and 
LGR5 to regulate Wnt/ $\beta$-catenin signaling. Proc Natl Acad Sci USA. 2011; 108:11452-57. https://doi.org/10.1073/ pnas. 1106083108 .

12. Nam JS, Turcotte TJ, Yoon JK. Dynamic expression of R-spondin family genes in mouse development. Gene Expr Patterns. 2007; 7:306-12. https://doi.org/10.1016/j. modgep.2006.08.006.

13. Bell SM, Schreiner CM, Wert SE, Mucenski ML, Scott WJ, Whitsett JA. R-spondin 2 is required for normal laryngealtracheal, lung and limb morphogenesis. Development. 2008; 135:1049-58. https://doi.org/10.1242/dev.013359.

14. Zhu YB, Xu L, Chen M, Ma HN, Lou F. GPR48 promotes multiple cancer cell proliferation via activation of Wnt signaling. Asian Pac J Cancer Prev. 2013; 14:4775-78. https://doi.org/10.7314/APJCP.2013.14.8.4775.

15. Steffen JS, Simon E, Warneke V, Balschun K, Ebert M, Röcken C. LGR4 and LGR6 are differentially expressed and of putative tumor biological significance in gastric carcinoma. Virchows Arch. 2012; 461:355-65. https://doi. org/10.1007/s00428-012-1292-1.

16. Gao Y, Kitagawa K, Hiramatsu Y, Kikuchi H, Isobe T, Shimada M, Uchida C, Hattori T, Oda T, Nakayama K, Nakayama KI, Tanaka T, Konno H, Kitagawa M. Up-regulation of GPR48 induced by down-regulation of p27Kip1 enhances carcinoma cell invasiveness and metastasis. Cancer Res. 2006; 66:11623-31. https://doi. org/10.1158/0008-5472.CAN-06-2629.

17. Wu J, Xie N, Xie K, Zeng J, Cheng L, Lei Y, Liu Y, Song L, Dong D, Chen Y, Zeng R, Nice EC, Huang C, Wei Y. GPR48, a poor prognostic factor, promotes tumor metastasis and activates $\beta$-catenin/TCF signaling in colorectal cancer. Carcinogenesis. 2013; 34:2861-69. https://doi.org/10.1093/ carcin/bgt229.

18. Liang F, Yue J, Wang J, Zhang L, Fan R, Zhang H, Zhang Q. GPCR48/LGR4 promotes tumorigenesis of prostate cancer via PI3K/Akt signaling pathway. Med Oncol. 2015; 32:49. https://doi.org/10.1007/s12032-015-0486-1.

19. Cho SW, Lee EJ, Kim H, Kim SH, Ahn HY, Kim YA, Yi KH, Park DJ, Shin CS, Ahn SH, Cho BY, Park YJ. Dickkopf-1 inhibits thyroid cancer cell survival and migration through regulation of $\beta$-catenin/E-cadherin signaling. Mol Cell Endocrinol. 2013; 366:90-98. https:// doi.org/10.1016/j.mce.2012.12.007.

20. Garcia-Rostan G, Camp RL, Herrero A, Carcangiu ML, Rimm DL, Tallini G. $\beta$-catenin dysregulation in thyroid neoplasms: down-regulation, aberrant nuclear expression, and CTNNB1 exon 3 mutations are markers for aggressive tumor phenotypes and poor prognosis. Am J Pathol. 2001; 158:987-96. https://doi.org/10.1016/ S0002-9440(10)64045-X.

21. Klonisch T, Hoang-Vu C, Hombach-Klonisch S. Thyroid stem cells and cancer. Thyroid. 2009; 19:1303-15. https:// doi.org/10.1089/thy.2009.1604.

22. Ríos Moreno MJ, Galera-Ruiz H, De Miguel M, López MI, Illanes M, Galera-Davidson H. Inmunohistochemical profile of solid cell nest of thyroid gland. Endocr Pathol. 2011; 22:35-39. https://doi.org/10.1007/s12022-010-9145-4.

23. Jin C, Yin F, Lin M, Li H, Wang Z, Weng J, Liu M, Da Dong $\mathrm{X}, \mathrm{Qu} \mathrm{J}, \mathrm{Tu} \mathrm{L}$. GPR48 regulates epithelial cell proliferation and migration by activating EGFR during eyelid development. Invest Ophthalmol Vis Sci. 2008; 49:4245-53. https://doi.org/10.1167/iovs.08-1860.

24. Lu Z, Ghosh S, Wang Z, Hunter T. Downregulation of caveolin-1 function by EGF leads to the loss of E-cadherin, increased transcriptional activity of $\beta$-catenin, and enhanced tumor cell invasion. Cancer Cell. 2003; 4:499-515. https:// doi.org/10.1016/S1535-6108(03)00304-0.

25. Ding Q, Xia W, Liu JC, Yang JY, Lee DF, Xia J, Bartholomeusz G, Li Y, Pan Y, Li Z, Bargou RC, Qin J, Lai CC, et al. Erk associates with and primes GSK-3 $\beta$ for its inactivation resulting in upregulation of $\beta$-catenin. Mol Cell. 2005; 19:159-70. https://doi.org/10.1016/j. molcel.2005.06.009.

26. Glinka A, Dolde C, Kirsch N, Huang YL, Kazanskaya O, Ingelfinger D, Boutros M, Cruciat CM, Niehrs C. LGR4 and LGR5 are R-spondin receptors mediating Wnt/ $\beta$-catenin and Wnt/PCP signalling. EMBO Rep. 2011; 12:1055-61. https://doi.org/10.1038/embor.2011.175.

27. McDonald T, Wang R, Bailey W, Xie G, Chen F, Caskey CT, Liu Q. Identification and cloning of an orphan $G$ protein-coupled receptor of the glycoprotein hormone receptor subfamily. Biochem Biophys Res Commun. 1998; 247:266-70. https://doi.org/10.1006/bbrc.1998.8774.

28. Sato T, Vries RG, Snippert HJ, van de Wetering M, Barker N, Stange DE, van Es JH, Abo A, Kujala P, Peters PJ, Clevers H. Single Lgr5 stem cells build crypt-villus structures in vitro without a mesenchymal niche. Nature. 2009; 459:262-65. https://doi.org/10.1038/nature07935.

29. Barker N, van Es JH, Kuipers J, Kujala P, van den Born M, Cozijnsen M, Haegebarth A, Korving J, Begthel H, Peters PJ, Clevers H. Identification of stem cells in small intestine and colon by marker gene Lgr5. Nature. 2007; 449:100307. https://doi.org/10.1038/nature06196.

30. de Lau W, Barker N, Low TY, Koo BK, Li VS, Teunissen H, Kujala P, Haegebarth A, Peters PJ, van de Wetering M, Stange DE, van Es JE, Guardavaccaro D, et al. Lgr5 homologues associate with Wnt receptors and mediate R-spondin signalling. Nature. 2011; 476:293-97. https:// doi.org/10.1038/nature10337.

31. Ruffner H, Sprunger J, Charlat O, Leighton-Davies J, Grosshans B, Salathe A, Zietzling S, Beck V, Therier M, Isken A, Xie Y, Zhang Y, Hao H, et al. R-Spondin potentiates $\mathrm{Wnt} / \beta$-catenin signaling through orphan receptors LGR4 and LGR5. PLoS One. 2012; 7:e40976. https://doi.org/10.1371/journal.pone.0040976.

32. Gong X, Yi J, Carmon K, Crumbley C, Xiong W, Thomas A, Fan X, Guo S, An Z, Chang J. Aberrant RSPO3-LGR4 signaling in Keap1-deficient lung adenocarcinomas promotes tumor aggressiveness. Oncogene. 2015; 34:4692-701. 
33. Han XH, Jin YR, Tan L, Kosciuk T, Lee JS, Yoon JK. Regulation of the follistatin gene by RSPO-LGR4 signaling via activation of the $\mathrm{WNT} / \beta$-catenin pathway in skeletal myogenesis. Mol Cell Biol. 2014; 34:752-64. https://doi. org/10.1128/MCB.01285-13.

34. Chen G, Jiang Q, You Z, Yao J, Mou L, Lin X, Shen X, You T, Lin Q, Wen J, Lin L. Regulation of GSK-3 beta in the proliferation and apoptosis of human thyrocytes investigated using a GSK-3 beta-targeting RNAi adenovirus expression vector: involvement the Wnt/beta-catenin pathway. Mol Biol Rep. 2010; 37:2773-79. https://doi. org/10.1007/s11033-009-9819-5.

35. Ishigaki K, Namba $H$, Nakashima $M$, Nakayama $T$, Mitsutake N, Hayashi T, Maeda S, Ichinose M, Kanematsu T, Yamashita S. Aberrant localization of $\beta$-catenin correlates with overexpression of its target gene in human papillary thyroid cancer. J Clin Endocrinol Metab. 2002; 87:3433-40.

36. Helmbrecht K, Kispert A, von Wasielewski R, Brabant G. Identification of a Wnt/ $\beta$-catenin signaling pathway in human thyroid cells. Endocrinology. 2001; 142:5261-66. https://doi.org/10.1210/endo.142.12.8554.

37. Sastre-Perona A, Riesco-Eizaguirre G, Zaballos MA, Santisteban P. $\beta$-catenin signaling is required for RAS-driven thyroid cancer through PI3K activation. Oncotarget. 2016; 7:49435-49. https://doi.org/10.18632/oncotarget.10356.

38. Castellone MD, De Falco V, Rao DM, Bellelli R, Muthu M, Basolo F, Fusco A, Gutkind JS, Santoro M. The $\beta$-catenin axis integrates multiple signals downstream from RET/papillary thyroid carcinoma leading to cell proliferation. Cancer Res. 2009; 69:1867-76. https://doi. org/10.1158/0008-5472.CAN-08-1982.

39. Cassinelli G, Favini E, Degl'Innocenti D, Salvi A, De Petro G, Pierotti MA, Zunino F, Borrello MG, Lanzi C. RET/ PTC1-driven neoplastic transformation and proinvasive phenotype of human thyrocytes involve Met induction and $\beta$-catenin nuclear translocation. Neoplasia. 2009; 11:10-21. https://doi.org/10.1593/neo.08916.

40. Kim KA, Kakitani M, Zhao J, Oshima T, Tang T, Binnerts M, Liu Y, Boyle B, Park E, Emtage P, Funk WD, Tomizuka $\mathrm{K}$. Mitogenic influence of human R-spondin1 on the intestinal epithelium. Science. 2005; 309:1256-59. https:// doi.org/10.1126/science.1112521.

41. Seshagiri S, Stawiski EW, Durinck S, Modrusan Z, Storm EE, Conboy CB, Chaudhuri S, Guan Y, Janakiraman V, Jaiswal BS, Guillory J, Ha C, Dijkgraaf GJ, et al. Recurrent R-spondin fusions in colon cancer. Nature. 2012; 488:660 64. https://doi.org/10.1038/nature11282.

42. Michelotti G, Jiang X, Sosa JA, Diehl AM, Henderson BB. LGR5 is associated with tumor aggressiveness in papillary thyroid cancer. Oncotarget. 2015; 6:34549-60. https://doi. org/10.18632/oncotarget.5330.

43. DeLellis RA. Pathology and genetics of tumours of endocrine organs. IARC; 2004.

44. Haugen BR, Alexander EK, Bible KC, Doherty GM, Mandel SJ, Nikiforov YE, Pacini F, Randolph GW, Sawka
AM, Schlumberger M, Schuff KG, Sherman SI, Sosa JA, et al. 2015 American Thyroid Association Management Guidelines for Adult Patients with Thyroid Nodules and Differentiated Thyroid Cancer: The American Thyroid Association Guidelines Task Force on Thyroid Nodules and Differentiated Thyroid Cancer. Thyroid. 2016; 26:1-133. https://doi.org/10.1089/thy.2015.0020.

45. Ghossein RA, Katabi N, Fagin JA. Immunohistochemical detection of mutated BRAF V600E supports the clonal origin of BRAF-induced thyroid cancers along the spectrum of disease progression. J Clin Endocrinol Metab. 2013; 98:E1414-21. https://doi.org/10.1210/jc.2013-1408.

46. Wang XJ, Kim A, Li S. Immunohistochemical analysis using a BRAF V600E mutation specific antibody is highly sensitive and specific for the diagnosis of hairy cell leukemia. Int J Clin Exp Pathol. 2014; 7:4323-28.

47. Lee SE, Lee JU, Lee MH, Ryu MJ, Kim SJ, Kim YK, Choi MJ, Kim KS, Kim JM, Kim JW, Koh YW, Lim DS, Jo YS, Shong M. RAF kinase inhibitor-independent constitutive activation of Yes-associated protein 1 promotes tumor progression in thyroid cancer. Oncogenesis. 2013; 2:e55. https://doi.org/10.1038/oncsis.2013.12.

48. Hwang JH, Kim DW, Suh JM, Kim H, Song JH, Hwang ES, Park KC, Chung HK, Kim JM, Lee TH, Yu DY, Shong M. Activation of signal transducer and activator of transcription 3 by oncogenic RET/PTC (rearranged in transformation/ papillary thyroid carcinoma) tyrosine kinase: roles in specific gene regulation and cellular transformation. Mol Endocrinol. 2003; 17:1155-66. https://doi.org/10.1210/me.2002-0401.

49. Kim DW, Jo YS, Jung HS, Chung HK, Song JH, Park KC, Park SH, Hwang JH, Rha SY, Kweon GR, Lee SJ, Jo $\mathrm{KW}$, Shong M. An orally administered multitarget tyrosine kinase inhibitor, SU11248, is a novel potent inhibitor of thyroid oncogenic RET/papillary thyroid cancer kinases. J Clin Endocrinol Metab. 2006; 91:4070-76. https://doi. org/10.1210/jc.2005-2845.

50. Kim SJ, Kwon MC, Ryu MJ, Chung HK, Tadi S, Kim YK, Kim JM, Lee SH, Park JH, Kweon GR, Ryu SW, Jo YS, Lee $\mathrm{CH}$, et al. CRIF1 is essential for the synthesis and insertion of oxidative phosphorylation polypeptides in the mammalian mitochondrial membrane. Cell Metab. 2012; 16:274-83. https://doi.org/10.1016/j.cmet.2012.06.012.

51. Lee MH, Lee SE, Kim DW, Ryu MJ, Kim SJ, Kim SJ, Kim YK, Park JH, Kweon GR, Kim JM, Lee JU, De Falco V, Jo YS, Shong M. Mitochondrial localization and regulation of BRAFV600E in thyroid cancer: a clinically used RAF inhibitor is unable to block the mitochondrial activities of BRAFV600E. J Clin Endocrinol Metab. 2011; 96:E19-30. https://doi.org/10.1210/jc.2010-1071.

52. Kim KS, Min JK, Liang ZL, Lee K, Lee JU, Bae KH, Lee MH, Lee SE, Ryu MJ, Kim SJ, Kim YK, Choi MJ, Jo YS, et al. Aberrant 11 cell adhesion molecule affects tumor behavior and chemosensitivity in anaplastic thyroid carcinoma. Clin Cancer Res. 2012; 18:3071-78. https://doi. org/10.1158/1078-0432.CCR-11-2757. 